Весна ДИЦКОВ

vesna.dickov@fil.bg.ac.rs

\title{
ОГЛЕДАЛА У ЛАВИРИНТУ: ПРЕВОДНА РЕЦЕПЦИЈА БОРХЕСОВИХ ТЕКСТОВА О КЮИЖЕВНОСТИ
}

Филолошки факултет, Београд

\begin{abstract}
Апстракт: Овај рад се бави преводном рецепцијом Борхесових текстова о књижевности који су објављени на српском језику у облику књига. Разматрани корпус је хетерогеног састава: поједина посебна издања обухватају искључиво једну врсту Борхесових текстова о књижевности, док су у другима обједињени различити прилози (есеји, предговори, предавања). Такође, сагледани су и преводи Борхесових текстова о књижевности који чине интегрални део антологија посвећених Борхесовом стваралаштву у целости. Примењујући хронолошки приступ и аналитичко-синтетички метод, приказују се и тумаче све релевантне компоненте истраженог рецепцијског процеса (развојна динамика, временске и естетичке дистанце, иновације, помоћне апаратуре, тиражи), као и његови непосредни учесници (преводиоци, приређивачи, издавачи, аутори предговора и/или поговора), са циљем да се укаже на специфична својства и значај преводне рецепције Борхесових текстова о књижевности, штампаних током XX и почетком XXI века у посебним издањима на српском језику.
\end{abstract}

Кључне речи: хиспаноамеричка књижевност, српска преводна књижевност, Хорхе Луис Борхес, предавања, есеји, предговори, рецепција

\section{Увод}

Хорхе Луис Борхес (Jorge Luis Borges, 1899-1986) започиње књижевно стваралаштво двадесетих година прошлог века писањем стихова под снажним утицајем ултраизма ${ }^{1}$, да би се убрзо, већ почетком

1 Ултраизам (шп. ultraísmo) назив је једног од водећих авангардних књижевних покрета на шпанском језичком подручју; појавио се у Шпанији крајем двадесетих година прошлог века под утицајем других авангардних токова, првенствено хиспаноамеричког креационизма (шп. creacionismo) и различитих авангардних покрета европског порекла: футуризма, дадаизма, експресионизма и кубизма. Трајао је као један од доминантних авангардних токова до средине треће деценије XX столећа, када његов утицај почиње да јењава прво у Шпанији, а потом и у Хиспанској Америци. Будући да се деловање ултраиста односило искључиво на обнову поезије, покрет није изазивао пажњу шире читалачке публике, али је међу песницима био изузетно уважаван. За време трогодишњег боравка у Шпанији непосредно након завршетка Првог светског рата, Хорхе Луис Борхес се подробно упознао са остварењима ултраиста, чија је поетска начела пренео, по повратку у Аргентину 1921. године, на књижевну сцену Буенос Ајреса, поставши тако главни заговорник и теоретичар овог покрета на хиспаноамеричком тлу. Борхесове прве три збирке песама - Fervor de Buenos 
треће деценије XX столећа, окренуо у великој мери прози. Напустивши авангардну поетику и њене прекомерне захтеве за стилским експериментисањем, као и локалне теме и ликове које је наметао креолизам ${ }^{2}$, Борхес је уобличио сопствени, аутентичан књижевни израз, заснован првенствено на изузетно богатом читалачком искуству, ерудицији и аналитичким склоностима, те ослобођен стега чврсте поделе на родове и врсте. Уз лудички приступ при уношењу фантастичних елемената у фикционалне творевине (приче и параболе), Борхес оспорава класично реалистичко приказивање објективне стварности и даје литерарно виђење света обогаћено фантастиком као природним, саставним чиниоцем свакодневице (Pavlović-Samurović 1993: 323). Негујући интертекстуалност и ауторефлексивност, Борхес ствара посебну врсту кратког фикционалног есеја који прераста у исходиште његовог критичког става у обради књижевне грађе, одређивању сопствених естетичких мерила, изналажењу литерарног надахнућа и развијању филозофских промишљања (Pérez 1999: 250). Борхесово књижевно стваралаштво које константно осцилира између рационалности и скептицизма, настојећи да понуди што потпунији и разноврснији увид у неисцрпну ризницу светских писаца и њихових дела, захтева од читаоца активну улогу током читавог рецепцијског процеса усвајања његових творевина.

Када је реч о посебним издањима на српском језику која су у целости посвећена књижевном опусу Хорхеа Луиса Борхеса, до иницијалног пробоја видокруга очекивања дошло је раних шездесетих година прошлог века објављивањем (1963. године) збирке Борхесових приповедака Машйарије. Док је, с једне стране, поменута

Aires (Оgушевљеюе Буенос Ајресом, 1923), Luna de enfrente (Месеи og ӣрекойуйа, 1925) и Cuaderno San Martín (Свеска Светии Марӣuн, 1929) - написане су под непосредним утицајем ултраизма.

2 Креолизам (шп. criollismo; потиче од именице criollo [креол], која на шпанском језику означава потомка Европљанина, најчешће Шпанаца, рођеног у некој од шпанских колонија на хиспаноамеричком тлу) књижевни је покрет настао у Хиспанској Америци крајем XIX столећа, у време јачања младих и независних република, са циљем да допринесе што бржем формирању самосталног, независног, аутохтоног књижевног израза у односу на утицаје који су долазили из Европе, посебно из Шпаније. У том смислу, теме (суочавање са неповољним природним силама и опресивним друштвеним околностима, социјални и психолошки проблеми, повратак животу на селу), ликови (типични за дато поднебље), ситуације (употпуњене фолклорним елементима) и језик (обогаћен колоквијалном лексиком) осликавају локалну средину, коју писци настоје да што верније представе, истичући значај хиспаноамеричке традиције и културе. Утицај креолизма је очигледан у целокупном књижевном стваралаштву младог Борхеса, нарочито се огледа у његовим делима насталим током треће деценије прошлог века, и то како у збиркама песама (Оgушевљене Буенос

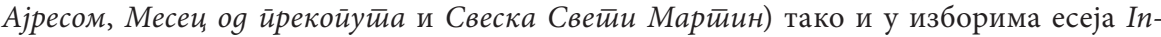
quisiciones (Истираживаюа, 1925), El tamaño de mi esperanza (Обим моје наge, 1926) и El idioma de los argentinos (Језик Аріенииинаца, 1928).

3 Збирку приповедака Машйарије превео је са шпанског језика Божидар Марковић, а објавио Нолит на иницијативу Васка Попе, уредника едиције „Метаморфозе“. 
преводна рецепција знатно каснила (скоро две деценије) у односу на објављивање оригинала ${ }^{4}$, њена појава је, с друге стране, била усаглашена са одјеком који је Борхесова збирка Машйарије добила на међународној књижевној сцени . Међутим, након штампања овог превода, код нас је уследила вишегодишња пауза у преводној рецепцији Борхесових дела у облику посебних издања, која је прекинута тек 1979. године објављивањем избора Крайке йриче ; прва збирка Борхесове поезије Изабране йесме п појавила на српском језику 1982. године, учврстивши примарне оквире хоризонта очекивања наше читалачке публике.

\section{Посебна издања на српском језику састављена искључиво од Борхесових текстова о књижевности}

Скоро истовремено са првом збирком Борхесових песничких творевина, појавило се на српском језику и прво посебно издање са текстовима овог хиспаноамеричког писца који су били посвећени књижевности: реч је о самосталном издању Предрага Марковића, Светислава Басаре, Михајла Пантића и Томице Милосављевића,

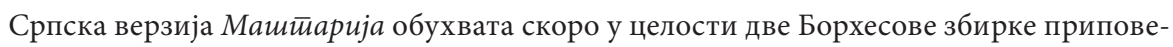

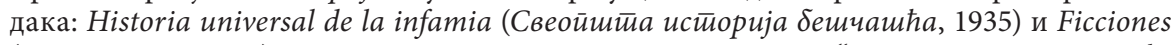
(Машйарије, 1944). Аутор предговора „Приповедач Борхес“ је Миодраг Павловић. Нолит је објавио још једно, прештампано издање Машйарија (1978. године у 4.000 примерака), док је Раideia објавила три издања Машӣарија, али у преводу Александра Грујичића (2000. године у 2.000 примерака, 2005. године у 3.000 примерака и 2006. године у 3.000 примерака).

4 Прво издање збирке Машйарије на шпанском језику објавила је 1944. године издавачка кућа Cyp (Sur), која је основана 1933. године у Буенос Ајресу, само две године након изласка из штампе првог броја истоименог авангардног књижевног часописа у чијем је уређивачком одбору био и Хорхе Луис Борхес. Покретање часописа Суp (Sur, 1931-1992), заслугом аргентинске књижевнице Викторије Окампо (Victoria Ocampo, 1890-1979), дало је немерљив замајац новим стремљењима не само у књижевности и хуманистичким наукама у Аргентини већ и у многим другим земљама Хиспанске Америке.

5 Хорхе Луис Борхес је поделио (1961. године) са ирским писцем Семјуелом Бекетом међународну књижевну награду Форментор (Premio Formentor de las Letras), коју додељује шпанска издавачка кућа Сеиш Барал (Seix Barral) са седиштем у Барселони; након добијања овог престижног признања, Борхес је стекао велику популарност код европске читалачке публике, а убрзо и широм света.

6 Збирка Кратике йриче, коју је приредила Кринка Видаковић Петров, садржи 21 Борхесову причу: 13 прича је изабрано из збирке Aleph (Алеф, 1949) и 8 прича из збирке El hacedor (Творииель, 1960); све одабране приче је превела са шпанског језика Кринка Видаковић Петров, а такође је написала и поговор „Борхесово схватање стварности и књижевности“. Након што је исцрпљено прво издање од 10.000 примерака, које је штампано у оквиру библиотеке џепних књига Реч и мисао, издавачка кућа Рад је објавила још три издања ове збирке $(1982,1999,2006)$.

7 Антологију Изабране иесме је у потпуности припремио Радивоје Константиновић (одабрао 94 песме из 13 Борхесових збирки, превео све песме са шпанског језика, написао предговор „Борхес песник“ и сачинио „Напомене“); ову збирку је објавила Српска књижевна задруга у тиражу од 4.000 примерака. 
које је изашло, у тиражу од 3.000 примерака, 1983. године у Београду под насловом Усмени Борхес и gруїа истираживана. Ова књига, невеликог обима (93 стране), садржи пет предавања ${ }^{8}$ и четири есеја․․ Предавања је Хорхе Луис Борхес одржао на Универзитету у Белграну (Universidad de Belgrano) ${ }^{10}$ у раздобљу од 24. маја до 25. јуна 1978. године, а објављена су 1979. године, поводом Борхесовог осамдесетог рођендана, у облику књиге Borges oral (Усмени Борхес), захваљујући Универзитету у Белграну и аргентинској издавачкој кући Емесе (Emecé Editores). Поред поменутих предавања, посебно издање Усмени Борхес и gруїа истираживана обухвата и огледе, који су одабрани из збирке Борхесових есеја Otras inquisiciones (Друїa ис-

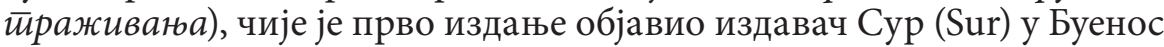
Ajrecy 1952. године. У превођењу текстова из збирке Усмени Борхес u gруїа истираживања са шпанског на српски језик учествовало је троје преводилаца: Анђелија Радовановић и Предраг Марковић су превели Борхесова предавања, док је есеје превела Радица Остојић.

Избор Усмени Борхес и gруїа иситраживања је састављен од превода текстова који су стигли на српско језичко подручје са великим распоном временских дистанци (4-29 година) у односу на појаву оригиналних верзија на шпанском језику. Међутим, без обзира на различиту темпоралну провенијенцију, све ове текстове прожима суштински скептицизам, који уједно представља - по речима Берната Кастанија Прада - исходиште како Борхесове космогоније тако и његовог целокупног књижевног стваралаштва на нивоу стила (скептична фразеологија, парадокс, дупла негација, елипса, хаотично набрајање), нарације (принцип кинеских кутија, перспективизам, алтерација ауторовог присуства) и фикције (лавиринт, библиотека, кабала, слепило), а нарочито је уочљив у криминалистичком жанру у којем детектив, сагледан као својеврсно оличење математичког ума и филозофског догматизма, ипак није у стању да превазиђе и надвлада сву сложеност универзума (Castany Prado 2006). Док, с једне стране, у предавању „Детективска прича“ истиче да је основна одлика ове подврсте постојање мистерије која се разрешава разумом, тј. интелектом, у процесу (емпиријском и дедуктивном) когнитивног карактера, Борхес, с друге стране, у есеју „О Честертону“коментарише приповедачки поступак овог енглеског писца - који је радо

8 „Књига“(„Ellibro“), „Бесмртност“(„La inmortalidad“), „Емануел Сведенборг“(„Emanuel Swedenborg“), „Детективска прича“ („El cuento policial“) и „Време“ („El tiempo“).

9 „Део чари Дон Кихота“ („Magias parciales del Quijote“), „О Честертону“ („Sobre Chesterton“), „Кафка и његове претече“ („Kafka y sus precursores“) и „О Вайеку Вилијама Бекфорда“" („Sobre el Vathek de William Beckford“).

10 Белграно (Belgrano) једна је од општина Буенос Аjpeca; основана је средином XIX века и представља један од најзначајнијих пословних и трговачких центара аргентинске престонице. Названа је по Мануелу Белграну (Manuel Belgrano, 1770-1820), адвокату, дипломати и генералу, истакнутом борцу за независност Аргентине од шпанске хегемоније и творцу аргентинске заставе. 
и са̂м примењивао - сачињен од комбинације низа фантастичних и натприродних хипотеза са рационалним, логичким разрешењима, те указује на повезаност и сродност основног устројства историје метафизике и науке са наративним проседеом детективских прича. Истичући у предавању „Време“ човекову тајанствену суштину, која се огледа у нераскидивом споју његових променљивих и трајних особина, Борхес скреће пажњу на немогућност изналажења коначног решења есенцијалних метафизичких проблема - питања времена и идентитета (Castany Prado 2006).

На крају књиге Усмени Борхес и gруїа истираживаға налази се текст „Загонетка Шекспира“, који је написао Јан Кот (Jan Kott), а превела са пољског језика Бисерка Рајчић. У овом тексту тестимонијалног карактера, који има функцију поговора, Кот предочава читаоцима низ личних утисака са Другог светског конгреса шекспиролога, одржаног априла месеца 1976. године у Вашингтону, на којем је учествовао и Борхес са предавањем „Загонетка Шекспира“. Котове реминисценције не садрже конкретна критичка вредновања нити књижевно-теоријска разматрања, већ се своде на дескрипцију, уобличену у својеврстан литерарни кроки, са примесама ироније и елементима Бахтинове карневализације ${ }^{11}$. Иако Котов текст несумњиво плени пажњу читалаца својом дескриптивном непосредношћу, траг који је оставио избор Усмени Борхес и gруїа истираживағь у њиховом хоризонту очекивања био би још упечатљивији да је ова књига била употпуњена одговарајућим прилозима критичког карактера (предговором и/или поговором). Ипак, треба имати у виду да је излазак из штампе посебног издања Усмени Борхес и gруїа истираживаюа омогућио, без обзира на поменуте мањкавости, формирање поуздане основе за даљу рецепцију Борхесове критичке и филозофске мисли на српском језичком подручју, захваљујући, пре свега, тематској разноврсности, као и књижевно-теоријском и естетичком значају одабраних и преведених текстова.

Средином осамдесетих година XX века изашао је избор Борхе-

11 „Međutim, na vrhuncu kongresa, dan uoči njegovog zatvaranja, trebalo je da izlaže Borhes. Borhes je specijalno došao na taj kongres. Sat ranije najveća sala Hiltona bila je popunjena do poslednjeg mesta. Samo su prva četiri reda stolica bila prazna. Školska deca su pazila da niko nepozvan ne sedne u njih. Ali, očigledno, zvanični gosti nisu došli i deca su na kraju sela u prve redove. Dva gospodina su vodila Borhesa. Išli su polako, držeći ga ispod ruke. Za trenutak mi se učinilo da vode figuru od drveta. Konačno su ga doveli na podijum ispred mikrofona. Čitava sala je ustala, ovacije su dugo potrajale. Borhes se nije pomerio. Najzad se aplauz utišao. Borhes je počeo mrdati usnama. Sa mikrofona je dopirao šum. U tom monotonom šumu s najvećim naporom mogla se uloviti samo jedna reč, koja se neprestano vraćala kao dozivanje s dalekog broda koje zaglušuje more: Šekspir, Šekspir, Šekspir... Mikrofon je bio postavljen suviše visoko. Međutim, niko u čitavoj sali se nije usudio da priđe i spusti mikrofon ispred slepog, starog pisca. Borhes je govorio čitav sat i čitav sat ponavljao samo reč - Šekspir, koja je dopirala do slušalaca. Za taj sat niko nije ustao, niti napustio salu. Tek kada je Borhes završio, svi su ustali i činilo se da se te ovacije u stojećem položaju neće nikada završiti“ (Kot 1983: 85). 
сових текстова о књижевности Оїлеgи о мейафори. Премда скромног обима (36 страна), ово посебно издање, објављено 1985. године у тиражу од 1.000 примерака као саставни део (књига бр. 18) библиотеке „Откривања“ нишког часописа за књижевност, уметност и културу Граяина, садржи осам Борхесових текстова које је одабрао Радивоје Константиновић: два есеја ${ }^{12}$ из збирке Historia de la eternidad (Историја вечности), чије је прво издање штампано 1936. године у Буенос Ајресу; три есеја ${ }^{13}$ из збирке Друга истраживања (који нису били заступљени у избору Усмени Борхес и друга истраживања) и три предговора која је Хорхе Луис Борхес написао за збирке песама El oro de los tigres (Злато тигрова, 1972), La rosa profunda (Дубока ружа, 1975) и La cifra (Шифра, 1981). Почетна два есеја је превела са шпанског језика Драгана Бабић, док је све остале текстове превео, такође са шпанског језика, Радивоје Константиновић, који је у време састављања збирке Огледи о метафори већ био овенчан престижном наградом „Милош Н. Ђурић“ Удружења књижевних преводилаца Србије за превод Борхесових Изабраних песама 1983. године.

На крају књиге Оїлеgи о метиабори налази се поговор „Борхесова метафора“, чији је аутор Радивоје Константиновић. Имајући у виду схватање метафоре код младог Борхеса, окренутог током боравка у Европи (1914-1921) првенствено збивањима у спољашњем свету, наспрам Борхеса из зрелог доба који ствара готово искључиво у самоћи, Константиновић истиче да је Борхесова ултраистичка авантура у већој мери проистицала из датих историјских и културолошких околности него што је била условљена неком специфичном, унутрашњом потребом или песничким темпераментом (Константиновић 1985: 34). Напустивши тридесетих година прошлог века поетска начела ултраиста, по којима метафору одликује апсолутна функционална независност, Борхес сагледава ову стилску фигуру као алузију на већ давно успостављене везе између ствари, које код читалаца подстичу стварање најразноврснијих сопствених (интимних, литерарних и филозофских) асоцијација. Оригиналност метафоре, без обзира на њену увек присутну препознатљивост, Борхес постиже користећи нове и неуобичајене комбинација речи (Константиновић 1985: 36). Целокупан књижевни опус Хорхеа Луиса Борхеса почива на изразито функционалним метафорама које могу да се сведу на ограничен и релативно мали број архетипских језичко-стилских изражајних средстава:

Циљ уметности, по Борхесу, јесте да сагледа битне односе човека и света, да се бави вечним темама као што су смрт, пролазност, смисао живота, срећа, човеков идентитет, а за њихово означавање песник користи

12 „Кенинзи“ („Las kenningar“) и „Метафора“ („La metáfora“).

13 „Пасквалова сфера“ („La esfera de Pascal“), „Колриџов цвет“( (La flor de Coleridge“) и „Од алегорија ка романима“ („De las alegorías a las novelas“). 
препознатљиве, вечне симболе, док метафоре треба да исказују суштине. Метафора је, дакле, супротна вербалној играрији и блештавој опсени, она је нека врста метафизичке неминовности. (Константиновић 1985: 36)

Радивоје Константиновић закључује да разумевање Борхесове метафоре омогућава читаоцу да проникне у суштину поетике целокупног стваралаштва овог писца, која је заснована на поимању књижевности као уметничке баштине бројних провенијенција и универзалног значаја у чијем непрекидном стварању активно учествују сви људи на овоме свету у различитим епохама (Константиновић 1985: 36).

Посебно издање Оїлеgи о метиафори пружило је читаоцима са српског језичког подручја нови увид у Борхесову есејистику и, тиме, утицало на проширење њиховог хоризонта очекивања. У том погледу, нарочито је значајна била иницијална рецепција збирке Исйорија вечностии, премда је реализована парцијално (на узорку два преведена есеја) и са закашњењем од скоро пола века (49 година). Опседнутост Хорхеа Луиса Борхеса егзистенцијалним темама (време, пролазност, смрт, вечност) потиче још из његове младости, када се формирао читајући дела Шопенхауера, Вилијама Џејмса, Расела и Валерија. Дубоко уверен у постојање кружног тока времена, Борхес претпоставља сопствено схватање историје, засновано на скептицизму, Хегеловом идеалистичком концепту сједињене теорије стварности и спекулативној филозофији историје. Данијел Балдерстон сматра да је Борхес имао, пре свега, прагматичан однос према историјским догађајима, проналазећи у њиховим узрочно-последичним везама неисцрпан извор литерарног надахнућа (Balderston 1993: 10-11). Као допринос будућој историји метафоре за коју се искрено надао да ће једног дана бити написана, Борхес у есејима „Кенинзи“ и „Метафора“ анализира уметничке домете овог песничког изражајног средства у односу на различите културне и књижевне традиције. Након бројних поређења изнетих у есеју „Метафора“, која неретко указују на потпуно неочекиване сродности („Ко би $а$ priori помислио да 'столица за љуљање' и 'Давид заспа уз своје родитеље' имају исти корен?"), Борхес истиче да би компаративни списак метафора могао да буде бесконачан (Борхес 1985: 19). С друге стране, Борхесов есеј „Пасквалова сфера“, у којем износи схватање да је светска историја у ствари потенцијална историја различитих интонација неколиких метафора, представља, према Балдерстону, одраз текстуалне природе универзума (Balderston 1993: 11).

Крајем педесетих година прошлог века Борхес је објавио у часопису Сур есеј „La personalidad de Buddha“ („Будина личност“), за који се сматра да представља, заједно са седам предавања која је одржао на тему будизма у Буенос Ајресу на Слободној школи високих студија (El Colegio Libre de Estudios Superiores) у раздобљу од 1949. до

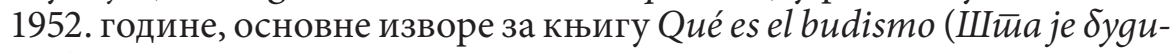
зам), која се појавила 1976. године као плод његове сарадње са арген- 
тинском књижевницом Алисијом Хурадо (Alicia Jurado). На измаку девете деценије XX века Силвија Монрос Стојаковић превела је ово дело са шпанског на српски језик и објавила га у Београду 1989. годи-

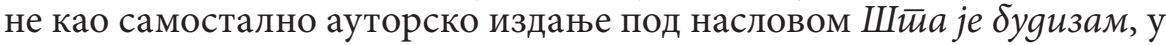
тиражу од 1.000 примерака. Ова књига садржи дванаест поглавља ${ }^{14}$ у којима се Борхес, разматрајући порекло и основне поставке будизма, бави метафизичким размишљањима о човековом бивствовању и развојном путу на овоме свету, реинкарнацији, срећи, слободи, смрти и постојању оностраног. Поред панорамског увода у будизам, читалац се среће и са Борхесовим освртима на погледе старогрчких филозофа (Питагора, Платон, Сократ, Аристотел, Плотин), мистичарских писаца (Алберуни, Џелалудин Руми), мислилаца из XVIII и XIX века (Хјум, Сведенборг, Шопенхауер, Емерсон, Бодлер, Шо, Леконт де Лил, Блејк), као и на његова размишљања везана за древну келтску поезију и хаику, традиционалну јапанску поетску форму.

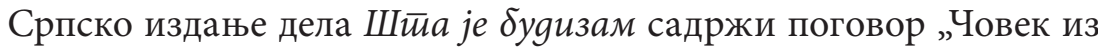
улице са ружичастим дућаном и људи у чаршавима боје шафрана“, који је написала Силвија Монрос Стојаковић са циљем да укаже на додирне тачке између будизма и Борхесовог свеколиког погледа на свет и књижевност. Полазећи од позитивистичких ставова Иполита Тена, Силвија Монрос Стојаковић истиче постојање географских, историјских и културолошких сличности (упечатљиви геоморфолошки контрасти, незаобилазно присуство крава у свакодневици становништва) између Аргентине, Борхесове домовине, и Индије, колевке будизма (Monros Stojaković 1989: 127-128). Мотив лавиринта као метафора вечне тајне света пред којом је људски ум неспособан да изнађе право решење, а да при томе не мора да се суочи са неизбежним разочарањем, приближава Борхеса у највећој могућој мери темељима будизма, где се суштински смисао човекове егзистенције препознаје у самом путовању, односно савладавању препрека, а не у досегнутом циљу (Monros Stojaković 1989: 133).

Будизам је филозофско учење које сврху човековог постојања налази у буђењу на индивидуалном нивоу и доспевању у стање нирване, када се постиже врхунска срећа и нестаје сва овоземаљска патња. Самсара - непрекидни ланац рађања, живота, смрти и поновног рађања - представља за будисте низање привида и може да се предупреди Нирваном, стањем врхунског блаженства које ослобађа од бола, страсти и непрекидног тока реинкарнације, а постиже се искључиво самоспознајом, односно, увежбавањем себе, баш као

14 „Легендарни Буда“ („El Buda legendario“), „Историјски Буда“ („El Buda histórico“), „Претече будизма“ („Antecedentes del budismo“), „Будистичка космологија“ („Cosmología budista“), „Сеоба душа“ („La transmigración“), „Будистичка учења“ („Doctrinas budistas“), „Велика кола“ („El gran vehículo“), „Ламаизам“ („El lamaísmo“), „Будизам у Кини“ („El budismo en la China“), „Тантрички будизам“ („El budismo tántrico“), „Зен будизам“ („El budismo zen“), „Будизам и етика“ („El budismo y la ética“). 
и воља за сазнањем коју Борхес досеже својим субјективним идеализмом (Monros Stojaković 1989: 136). С једне стране, Борхесови фантастични светови обилују елементима запрепашћења, док, с друге стране, будисти да би пронашли одговор изван правила логичког закључивања и подстакли тренутно пробуђење, то јест сатори, примењују праксу засновану на решавању коана (тј. загонетке или парадокса), који за Борхеса има дејство успелог вица, јер спаја најразличитије равни размишљања уз највећу економију употребљених изражајних средстава, ослобађајући при томе енергију чисте апстракције, сразмерну сажетости којом су обухваћене приземне прилике и нарави човека (Monros Stojaković 1989: 143).

Ауторка поговора указује на још неколике сличности између будиста и Борхеса (циклично поимање времена, поистовећивање појединца са појавама уместо западњачког рашчлањивања), те закључује да једноставност Борхесовог књижевног дискурса и сведеност његовог приповедачког поступка одговарају у потпуности источњачкој концизности у размишљању (Monros Stojaković 1989: 142). На крају поговора појашњене су извесне специфичности у преводу (транскрипције индијских речи, препеви индијских примера), као и улога Алисије Хурадо у припреми овог Борхесовог рукописа за штампу.

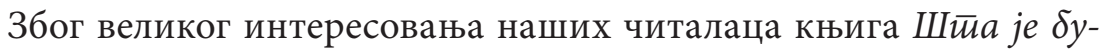
gизам вишеструко је прештампавана у Београду током XX века, достигавши (према расположивим подацима) укупан тираж од 8.000 примерака: прво је издавачка кућа Бата реализовала (1990. и 1991. године) два издања у тиражима од 3.000 примерака, а потом је Силмир објавио ово дело два пута самостално (1994. године у тиражу од 1.000 примерака и 1995. године, без податка о броју штампаних примерака) и једанпут (1999. године, без наведеног тиража) у сарадњи са београдским издавачем No limit books.

Прилика да се боље упозна са Борхесом као аутором предговора, као и са његовим књижевним укусом уопште, указала се нашој читалачкој публици 1990. године када је београдски издавач Стилос објавио, у тиражу од 2.000 примерака, књигу Преgіовори. Ово посебно издање се састоји од шездесет шест Борхесових предговора ${ }^{15}$,

15 „Хулио Кортасар: Приче“ („Julio Cortázar: Cuentos“); „Апокрифна јеванђеља“ („Evangelios Apócrifos"); „Франц Кафка: Америка. Крайке ириче“ („Franz Kafka: América. Relatos Breves“); „Џилберт Кејт Честертон: Плав крсти и gруіе йриче“ („Gilbert Ketth Chesterton: La Cruz Azul y Otros Cuentos“); „Вилијам Вилки Колинс: Месечев камен“ („Wilkie Collins, La piedra lunar“); „Морис Метерлинк: Иниеелиіенција ивећа“ („Maurice Maeter-

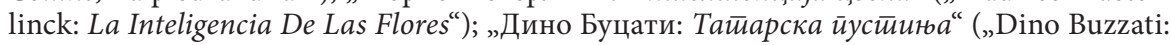
El Desierto De Los Tártaros“); „Хенрик Ибзен: Пер Гинй. Хеgа Габлер“ („Henrik Ibsen: Peer Gynt. Hedda Gabler"); „Жозе Марија Еша Де Кеирош: Манgарин“ („José María Eca De Queiroz: El Mandarín“); „Леополдо Лугонес: Језуийско изарсииво“ („Leopoldo Lugones: El Imperio Jesuítico“); „Андре Жид: Ковачи лажно̄ новиа“ („André Gide: Los Monederos Falsos"); „Херберт Џорџ Велс: Времейлов. Невияливи човек“ („Herbert George Wells: La Máquina Del Tiempo. El Hombre Invisible“); „Роберт Грејвс: Грчки мийови“ („Robert 
Graves: Los Mitos Griegos“); „Фјодор Достојевски: Зли gуси“ („Fiodor Dostoievski: Los De-

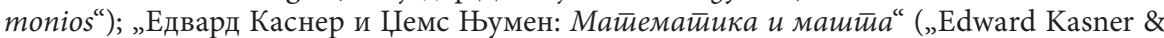
James Newman:Matemáticas E Imaginación“); „Јуџин О’Нил: Велики бої Браун. Необична

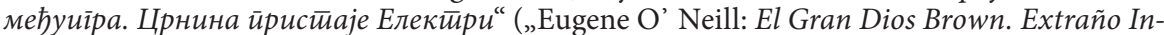
terludio. El Luto Le Sienta A Electra“); „Аривара Но Нарихира: Исеове йриче“ („Ariwara No Narihira: Cuentos De Ise“); „Херман Мелвил: Бенитио Серено. Били Буg. Писар Беритлби“ („Hermann Melville: Benito Cereno. Billy Budd. Bartleby, El Escribiente“); „Ђовани Папини:

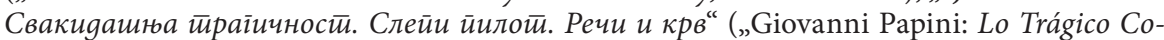
tidiano. El Piloto Ciego. Palabras Y Sangre“); „Артур Мејчен: Три варалице“ („Arthur Machen: Los Tres Impostores“); „Фра Луис де Леон: Песма наg йесмама. Излаїаюе књиіе o Јову“ („Fray Luis De León: Cantar De Cantares. Exposición Del Libro De Job“); „Џозеф

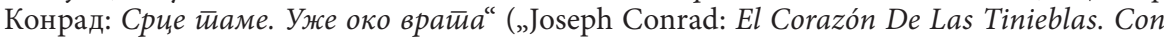

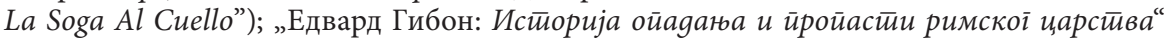
(„Edward Gibbon, Páginas de historia y de autobiografía“); „Оскар Вајлд: Оїлеgи и gијалози“ („Oscar Wilde: Ensayos Y Diálogos"); „Анри Мишо: Варварин у Азији“ („Henri Michaux: Un Bárbaro En Asia“); „Херман Хесе: Иїра сйаклених иеерли“ („Hermann Hesse: El Juego De Los Abalorios"); „Енок А. Бенет: Жив сахранен“ („Enoch A. Bennett: Enterrado En Vi da“); „Клаудије Елијан: Истиорија животииға“ („Claudio Eliano: Historia De Los Animales“); „Торстејн Веблен. Теорија о gоконој класи“ („Thorstein Veblen: Teoría De La Clase Ociosa"); „Гистав Флобер: Искушень Св. Анйонија“ („Gustave Flaubert: Las Ten-

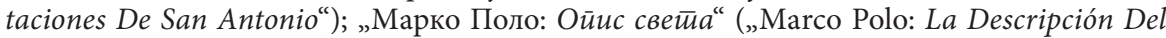
Мипdo"); „Марсел Швеб: Измишљени живоиеи“ („Marcel Schwob: Vidas Imaginarias"); „Џорџ Бернард Шо: Цезар и Клеойайра. Зайовеgница Барбара. Канgиgа“ („George Bernard Shaw: César Y Cleopatra. La Comandante Bárbara. Cándida“); „Франсиско Де Кеведо: Cрећа са мозі̄ом и час свију. Марко Бруй“ („Francisco De Quevedo: La Fortuna Con Seso Y La Hora De Todos. Marco Bruto"); „Еден Филпотс: Црвени Реgмејн“ („Eden Phillpotts: Los Rojos Redmayne"); „Серен Киркегор: Cйрах и gрхйане“ („Sören Kierkegaard: Temor Y Temblor"); „Густав Мајринк: Голем“ („Gustav Meyrink: El Golem“); „Хенри Џејмс:

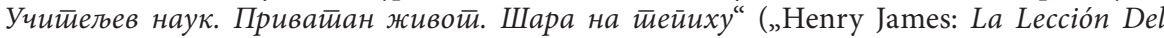
Maestro. La Vida Privada. La Figura En La Alfombra“); „Херодот: Девети кюиїа истиорије“ („Heródoto: Los Nueve Libros De La Historia“); „Хуан Рулфо: Пеgро Парамо“ („Juan Rulfo: Pedro Páramo"); „Радјард Кплинг: Приче“ („Rudyard Kipling: Relatos“); „Вилијам Бекфорд: Вайхек“ („William Beckford: Vathek“); „Данијел Дефо: Прилике и неирилике чувене Мол Фланgерс“ („Daniel Defoe: Las Venturas Y Desventuras De La Famosa Moll Flanders"); „Жан Кокто: Професионална т̄ајна и gруїи сйиси“ („Jean Cocteau: El Secreto Profesional Y Otros Textos“); „Томас Де Квинси: Послеgюи gани Емануела Канйа и gруїи сйucu“ („Thomas De Quincey: Los Últimos Días De Emmanuel Kant Y Otros Escritos“); „Рамон Гомес Де Ла Серна: Преgіовор gелу Силверија Лансе“ („Ramón Gómez De La Serna: Prólogo A La Obra De Silverio Lanza“); „(Избор Антоана Гланда): Хильаgy и јеgна ноћ“ („[Selección De Antoine Galland]: Las Mil Y Una Noches“); „Роберт Луис Стивенсон: Нове арайске ноћи. Мархајм“ („Robert Louis Stevenson: La Nuevas Noches Árabes. Markheim“); „Леон Блој: Сйасеюе Јевреја. Крв сиромаха. У йомрчини“ („Léon Bloy: La Salvación Por Los Judios. La Sangre Del Pobre. En Las Tinieblas“); „Бхаїaвag-Гийa. Сӣeв о Гилїамешу“ („Bhagavad-Gita. Poema De Gilgamesh“); „Хуан Хосе Ареола: Фанйасииччне йриче“ („Juan José Arreola: Cuentos Fantásticos"); „Дејвид Гарнет: Og gаме gо лисице. Човек у зоолошком

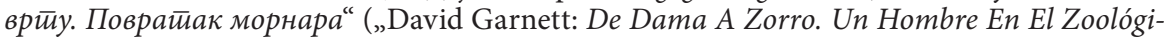
co. La Vuelta Del Marinero“); „Џонатан Свифт: Гуливерова йуйоваюа“ („Jonathan Swift: Viajes De Gulliver"); „Пол Грусак: Кюижевна крийика“ („Paul Groussac: Crítica Literaria“); „Мануел Мухика Лајнес: Иgоли“ („Manuel Mujica Lainez: Los Ídolos“); „Хуан Руис: Кюиїa goбре тьубави“ („Juan Ruiz: Libro De Buеn Amor“); „Вилијам Блејк: Сабране иеесме“

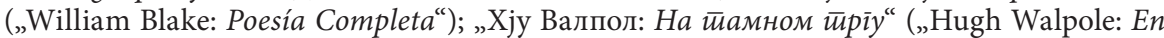
La Plaza Oscura“); „Есекијел Мартинес Естрада: Песничко gело“ („Ezequiel Martínez Estrada: Obra Poética“); „Едгар Алан По: Приче“ („Edgar Allan Poe: Cuentos“); „Публије Вергилије Марон: Енеjga“ („Publio Virgilio Marón: La Eneida“); „Волтер: Приче“ („Voltaire: Cuentos“); „Џ. В. Дун: Оїлеg са временом“ („J. W. Dunne: Un Experimento Con El Tiem- 
које је превела са шпанског језика Силвија Монрос Стојаковић, користећи као извор дело Biblioteca personal. Prólogos (Лична библиоте$\kappa a$. Предговори), штампано у Мадриду 1988. године. Прихвативши позив који му је упутила 1984. године аргентинска издавачка кућа Хиспамерика (Hyspamérica), Борхес се посветио - искључиво у складу са сопственим литерарним афинитетима - састављању списка од сто репрезентативних наслова из светске књижевне баштине. Томови Борхесове Личне библиотеке излазили су једном недељно од маја 1985. године све до ауторове смрти, допуњени одговарајућим предговорима, као и једним општим предговором који се односио на поменуту едицију у целости. На почетку српске верзије Предговора налази се „Напомена уз овај избор“, у којој се објашњава порекло ових Борхесових предговора, а на крају су штампани додаци („Списак наслова Личне библиотеке за које је Х. Л. Борхес написао предговор“, „Списак наслова објављених без предговора Х. Л. Борхеса“, „Списак наслова из првобитног избора Х. Л. Борхеса које је изоставио из коначног избора“) и завршни текст („У поговору предговорима“) Силвије Монрос Стојаковић у којем се истиче њихов књижевно-естетички значај:

Prepoznatljiv je u ovim predgovorima čitav niz Borhesovih konstanti, počev od sklonosti ka zagonetkama koje se protežu od metafizičkih konstrukcija pa sve do detektivskih zapleta, a zaključno sa Borhesovim načinom kazivanja koji je takođe i neretko zagonetan. S jedne strane subjektivna opredeljenja i lične sudove Borhes iznosi uz samosvesnu neprikosnovenost; s druge strane, rečenica kojom to čini često izmiče potpunom tumačenju i, svojim obiljem odnosnih zamenica, namerno ostaje dvosmislena. (Monros Stojaković 1990: 147)

Првобитни списак одабраних наслова посебно привлачи пажњу ауторке поговора, јер „садржи скривеног Борхеса“, оног правог који је „посегао за женом“, определивши се за дела Маргерит Јурсенар и Сапфо, која је, ипак, изоставио у коначном избору, највероватније, под утицајем шире јавности (Monros Stojaković 1990: 147-148). Београдски издавач Силмир објавио је ову компилацију Борхесових предговора још у два наврата током ХХ века, оба пута (1995. и 1999. године) под насловом Шійа йоново чийам (Преgіовори) и у тиражима од 1.000 примерака.

Исте (1990) године када се појавило прво Стилосово издање Борхесових Преgіовора издавачка кућа Рад из Београда је објавила у оквиру библиотеке Реч и мисао (са тиражем од 6.000 примерака) збирку Усмени Борхес, која представља прво издање дела Borges oral на српском језику као засебну књигу. Превод са шпанског језика

ро“); „Атилио Момиљано: Оїлеg о Бесном Орланgу“ („Attilio Momigliano: Ensayo Sobre

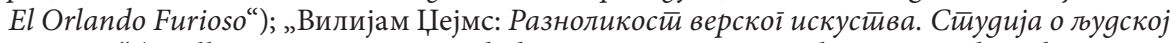
üpupogu“ („William James: Las Variedades De La Experiencia Religiosa. Estudio Sobre La Naturaleza Huтапа“); „Снори Стурлусон: Саїа о Еїил-Скалаірримсону“ („Snorri Sturluson: Saga De Egil Skallagrimsson"). 
Анђелије Станојевић и Предрага Марковића, који је овом приликом штампан, већ је једном био објављен 1983. године у оквиру збирке Усмени Борхес и gруіа истираживаға, али тиме рецепцијски значај поменутог Радовог посебног издања није нимало умањен. Збирка предавања Усмени Борхес заузима значајно место у дијахронијској равни преводне српске књижевности захваљујући, пре свега, заступљеној тематици. Наиме, свих пет предавања из ове збирке пружају увид у одабране теме (књига, бесмртност, Сведенборг, детективска прича, време) којима се Борхес, по сопственом признању, предано бавио дуги низ година ${ }^{16}$.

На крају збирке Усмени Борхес налази се поговор „Он, Борхес први и други“, који је написао Предраг Марковић, са циљем да представи Борхеса првенствено у улози предавача. Почев од 1949. године, када је имао први јавни наступ, Хорхе Луис Борхес је до краја свог живота, упркос урођеној стидљивости, одржао велики број предавања широм света и на тај начин је његов говорнички дар, за који Силвина Окампо тврди да је флуиднији и директнији од списатељског, дошао у потпуности до изражаја пред најширим аудиторијумом (Marković 1990: 76). Аутор поговора указује на сличности (инстинктиван осећај за форму, мисаоност, ерудицију, богатство идеја, једноставност и лепоту изражавања) између Борхеса који пише и Борхеса који говори, али и на одлике (специфичну топлину, хитрину и спонтаност говора) својствене Борхесовим предавањима, које нису присутне у његовим, вишеструко и веома пажљиво прерађиваним текстовима (Marković 1990: 77). Такође, пружа читаоцима сажету и нужно метафоричну слику Борхеса, који је, још у младости, одлучио да упозна свет помоћу читања, филозофског и метафизичког размишљања, те писања различитих књижевних дела - есеја, које многи сматрају „интелектуалним дендизмом“; песама за које неки кажу да „одишу помпезношћу и реторичношћу“ и прича са прећутним референцама на свакодневни живот - стварајући на тај начин богат литерарни опус, саткан од цртица и напомена, вешто поновљених метафора (тигар, библиотека, огледало, лавиринт), узгредних вербалија и накратко материјализованих привида, које одликује склоност ка претеривањима и парадоксалним закључцима (Marković 1990: 78-79). На крају поговора закључује се да Борхес своја лична запажања претвара у предавањима у универзалне констатације, непрестано истичући, при томе, сопствену усамљеност, издвојеност, неслагање са општепризнатим вредностима у име одбране достојанства непостојећег конзерватизма, као и специфич-

16 „Prvo, knjiga, taj instrument bez kojega ne mogu da zamislim svoj život, i koji za mene nije manje ličan negoli ruke ili oči. Drugo, besmrtnost, te pretnja ili nada o kojoj su tolike generacije sanjale koju traži poezija. Treće, Svedenborg, vizionar koji je napisao da mrtvi biraju pakao ili nebo slobodnom odlukom svoje volje. Cetvrto, detektivska priča, ta stroga igračka koju nam je Edgar Alan Po ostavio u nasledstvo. Peto, vreme, koje za mene i dalje predstavlja esencijalni problem metafizike." (Borhes, Usmeni Borhes, 1990: 3) 
ну недоследност у схватању историјских података и ништа мање специфично осећање хумора (Marković 1990: 80). Вођен Борхесовом идејом о интерактивном преплитању свих учесника у свеобухватном рецепцијском односу према књижевности, писац поговора истиче да је, заједно са Анђелијом Станојевић, настојао да у процесу превођења сачува специфичан облик ауторове усмене речи, односно, „повремену језичку храпавост“ и „синтаксичку рогобатност“, а да на читаоцима остаје да коначно утврде и оцене колико су у том подухвату преводиоци били успешни (Marković 1990: 81).

Средином последње деценије XX века, новосадски издавач Светови је објавио (1995. године) избор Оіллеgало заїонейки: есеји о

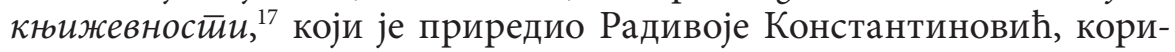
стећи следеће изворе из Борхесове књижевне заоставштине: Prosa completa (Сабрана йроза, 1980), Obra pоética (Песничко gело, 1980), La cifra (Шифра, 1981) и Siete noches (Сеgам ноћи, 1980). На превођењу текстова са шпанског на српски језик били су ангажовани Радивоје Константиновић, Драгана Бајић и Марина Љујић. Књига Оілеgало заі̄онейки садржи петнаест есеја (три есеја из збирке огледа Расйрава [Discusión, 1932; проширено издање 1957] ${ }^{18}$, три есеја из збирке

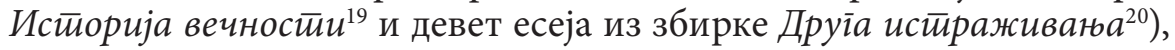
као и три предговора ${ }^{21}$ и два јавна предавања ${ }^{22}$ која је Борхес одржао током лета 1977. године у буеносајреском позоришту Колисео (Coliseo). Приређивач је представио, у изузетно широком временском дијапазону од скоро пола века (почев од огледа „Друкчији Витмен“ и „Трајање пакла“ из 1932. године до предговора збирци

17 За наслов избора Оїлеgало заі̄онет̄ки приређивач Радивоје Константиновић је искористио наслов Борхесовог есеја „Огледало загонетки“ („El espejo de los enigmas“) из збирке Друіа истираживаюа.

18 „Друкчији Витмен“ („El otro Whitman“) и „Трајање пакла“ („La duración del infierno“) преузети су из првог издања збирке Расйрава, које је објављено 1932. године, док је есеј „Флобер и његова узорна судбина“ („Flaubert у su destino ejemplar“) написан касније (1954. године) и чини саставни део проширеног издања збирке Расиррава из 1957. године. 19 „Историја вечности“ („Historia de la eternidad“), „Кенинзи“ и „Метафора“.

20 „Зид и књиге („La muralla y los libros“), „Пасквалова сфера“, „Колриџов цвес“, „Скривене чаролије Дон Кихота“, „Кафка и његове претече“, „О култу књига“ („Del culto de los libros“), „Китсов славуј“ („El ruiseñor de Keats“), „Огледало загонетки“ („El espejo de los enigmas“) и „Облици једне легенде“(„Formas de una leyenda“).

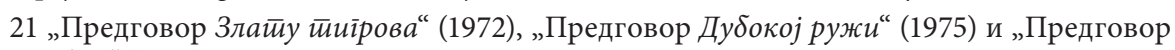
Шифри“ (1981).

22 Предавање „Божанствена комедија“ („La divina comedia“) одржано је 1. јуна 1977. године, а предавање „Поезија“ („La poesía“) 13. јула исте године; ова два предавања спадају у циклус сачињен од седам јавних предавања која је Борхес одржао у периоду од 1. јуна до 3. августа 1977. године у буеносајреском позоришту Колисео. Под покровитељством мексичке издавачке куће Фондо де култура економика (Fondo de Cultura Económica) и уз Борхесово одобрење и сарадњу, Рој Бартоломеу (Roy Bartholomew) уобличио је, на основу тонских записа, текстове свих поменутих седам предавања у посебно издање које је под насловом Siete noches (Cegaм ноћu) изашло из штампе 1980. године. 
песама Шифра из 1981. године), Хорхеа Луиса Борхеса као есејисту, предавача и књижевног критичара, особеног мислиоца посвећеног промишљању најразличитијих метафизичких и књижевних тема (вечност, метафора, књига, огледало), као и врсног тумача дела парадигматских писаца (Флобер, Витман, Китс, Колриџ, Кафка). Иако су поједини текстови ${ }^{23}$, од њих укупно двадесет који улазе у састав избора Оілеgало заїонеики, били већ одраније познати нашим читаоцима, ово посебно издање је одиграло веома значајну улогу у ширењу хоризонта очекивања публике са српског језичког подручја захваљујући донетим новинама, односно, оним Борхесовим текстовима који су овом приликом први пут били штампани на српском језику: реч је како о предавањима одабраним из збирке Сеgам ноћи, која су преведена на српски језик са петнаест година закашњења,

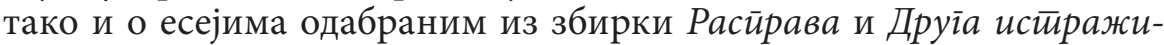
вағь дистанца (43 до 63 године).

Збирка Друі̄a истираживаға представља врхунац Борхесове зреле тематике и књижевног дискурса. Стога су есеји преузети из овог дела, који су први пут објављени у преводу на српски језик у склопу посебног издања Оїлеgало заїонейки, извршили особит утицај на модификовање видокруга очекивања наших читалаца. Есеј „Зид и књиге“ садржи Борхесову дефиницију естетичког чина као непосредне близине откровења, које се, међутим, у стварности не догађа (Борхес, Оїлеgало заїонейки, 1995: 71). Есеј „О култу књига“ доноси суштину Борхесове поетике у којој средишње место заузима „бескрајна књига“ као „једина ствар која постоји на овом свету; боље рећи, она је сам свет“ (Борхес, Оїлеgало заїонейки, 1995: 96). Есеј „Огледало загонетки“ скреће пажњу на Борхесово уверење да целокупна историја света, а према томе у оквиру ње и историја свих наших појединачних живота са припадајућим најситнијим појединостима, има значење које се не може ни симболично наслутити (Борхес, Оїлеgало заі̄онейки, 1995: 102). Есеј „Облици једне легенде“ одражава Борхесов став да легенда репродукује стварност уз мања небитна одступања и омогућава јој да кружи светом и да се преноси од уста до уста (Борхес, Оіллеgало заїонейки, 1995: 107).

Збирка Оїлеgало заїонейки: есеји о кюижевностии употпуњена је одговарајућим прилозима („Објашњења и коментари“, „Напомена приређивача“), које је, уз „Поговор“, припремио Радивоје Константиновић. Скрећући пажњу на значајно место које у обимном Борхесовом опусу заузимају текстови о књижевности, као и на њихову формалну разноврсност (огледи, предговори, предавања, критике, прикази, хронике), Константиновић истиче да полазну тачку Бор-

23 „Метафора“ и „Кенинзи“ објављени су у збирци Оїлеgu о метиафори, а „Пасквалова сфера“, „Колриџов цвет“, „Скривене чаролије Дон Кихота“ и „Кафка и његове претече“ изашли су у збирци Усмени Борхес и gруїа истираживаға. 
хесових књижевних анализа представља пажљиво читање оригиналних текстова, те да је Борхес још тридесетих година прошлог века приступао књижевном тексту онако како ће то много касније, тек шездесетих, чинити структуралисти (Константиновић 1995: 177). „Борхесове огледе о књижевности, који често садрже елементе приче или песме у прози, карактерише спој ерудиције и лакоће излагања. Његови огледи су по правилу кратки, препуни података и неочекиваних приближавања, а писани са бриљантном ноншалантношћу (Константиновић 1995: 177).“ Аутор поговора указује на Борхесово поимање светске књижевности као недељиве целине у којој „сви писци пишу једну књигу“, а он са̂м, захваљујући својој изузетној ерудицији, с лакоћом продире у суштину најразличитијих литерарних искустава од скандинавских сага до старе јапанске поезије. Константиновић сматра да је Борхесова страст према читању несумњиво одредила његов целокупан однос према књижевности, доприневши умногоме стварању иновативног критичког проседеа:

Пре Јауса и европских теоретичара књижевности Борхес указује на проблем рецепције књижевног дела, на читаоца као коаутора, читаоца који различитим читањем мења дело. Чини се да је посебно место које Борхес даје читаоцу и најважнија одлика Борхесове критичке методе. Борхес приступа тексту као читалац, „читалац хедонист“ (то су његове речи) и учи нас (пре Ролана Барта) да у књижевном тексту тражимо задовољство. (Константиновић 1995: 178)

На самом крају ХХ века издавачка кућа Народна књига - Алфа објавила је (1999. године) у Београду избор огледа Хорхеа Луиса Бор-

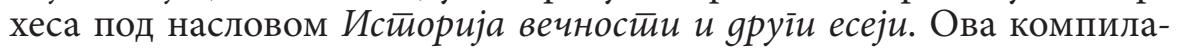
ција обухвата Борхесову збирку есеја Истиорија вечностии у целости (са свих осам ${ }^{24}$ припадајућих огледа), као и есеје одабране из још две Борхесове збирке (пет ${ }^{25}$ огледа из збирке Друїа истираживана и три ${ }^{26}$ есеја из збирке Расйрава). Свих шеснаест текстова је превела са шпанског језика Кринка Видаковић Петров. Збирка Исйорија веч-

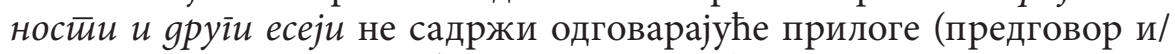
или поговор, напомене, белешке, регистре), нити назначене податке о приређивачу и штампаном тиражу, али заузима значајно место у дијахронијском низу српске преводне књижевности захваљујући

24 „Историја вечности“, „Кенингар“, „Метафора“, „Учење о циклусима“ („La doctrina de los ciclos"), „Кружно време“ („El tiempo circular“), „Преводиоци 1001 ноћи“ („Los traductores de las 1001 noches"), „Приближавање Алмотасиму“ („El acercamiento a Almotasim“) и „Вештина вређања“ („Arte de injuriar“).

25 „Зид и књиге“, „Колриџов цвет“, „Колриџов сан“ („El sueño de Coleridge“), „Време и Џ. В. Дан“ („El tempo у J. W. Dunne“) и „Ново побијање времена“ („Nueva refutación del tiempo“).

26 „Бесконачна трка Ахила и корњаче“ („La perputua carrera de Aquiles y la tortuga “), „Одбрана лажног Базилида“ („Una vindicación del falso Basilides“) и „Одбрана Кабале“ („Una vindicación de la cabala“). 
новинама којима је утицала на проширење хоризонта очекивања наших читалаца: само пет огледа из поменутог избора било им је познато одраније, а збирку Исйорија вечносичи могли су први пут да читају у целости на српском језику. Међутим, прво посебно издање које је у потпуности било посвећено искључиво Борхесовој збирци есеја Истиорија вечности и појавило се код нас тек почетком XXI века, када су уметничко друштво Градац из Чачка и Бранко Кукић, београдски песник и есејиста, објавили (2005. године) ово дело у преводу са шпанског језика Милана Комненића, у виду засебне књиге (такође без пратећих текстова) са тиражем од 500 примерака.

У оквиру Борхесовог књижевног опуса збирка Истиорија вечно$c \bar{u} u$ одражава ауторова стремљења ка уобличавању поетике свог, првенствено, прозног стваралаштва. У том смислу, два есеја из ове збирке су од посебне важности, истиче Алберто Хулијан Перес: есеј „Историја вечности“ указује на Борхесово удаљавање од реалистичког погледа на свет и учвршћивање његовог скептичног уверења да метафизичке идеје, будући да су подложне сталном процесу промена у човековој потрази за апсолутним, представљају открића фантастичног карактера која одликује пластичност и аутономија, док се у есеју „Приближавање Алмотасиму“ Борхес опредељује за еклектичну примену елемената тадашњих доминантних књижевних пракси, замењујући авангардни модел спонтаног стварања симболистичким поступком рационализоване формализације, што је довело до појаве једне од његових најуспешнијих наративних творевина - фиктивног књижевног чланка или белешке (la nota o artículo literario ficticio) - у којој излаже сопствене естетичке идеје и додељује фикционални карактер ванкњижевним облицима (Pérez 1992: 18-19). У циљу изналажења одговарајућег књижевног проседеа којим би могао да изрази своја бројна интелектуална интересовања, Борхес се током даљег сазревања све више удаљавао од авангарде, окрећући се естетичким поставкама симболизма. Полазећи од премисе да основни задатак и вредност уметности леже у учествовању у процесу хуманизације посредством ауторефлексије и самоспознаје сопствене егзистенцијалне ништавости, Борхес настоји да се задржи у ванвременској равни, ослобођеној историјског контекста, у којој дијалектички развој уметности посматра заустављен и сублимиран у једном показном тренутку спекулације, те у есеју „Ново побијање времена“ (из збирке Друїа исйраживања) негира не само постојање времена и простора већ и самога себе (Pérez 1992: 23).

Збирка Друі̄a истираживаюа представља аксијално дело, чија је функција на плану књижевне есејистике, по мишљењу Висентеа Сервера Салинаса, сродна оној која у погледу поетског стваралаштва - како у прози тако и у стиху - припада збирци El Hacedor (Творийељ, 1960) (Cervera Salinas 2017: 52). Есеји из збирке Друїа исираживаюа, настали у средишњој фази Борхесовог стваралаштва 
(између првих песама из двадесетих година и последњих стихова које је написао осамдесетих година прошлог века), пружају увид у енциклопедијски опсег ауторових интелектуалних интересовања, док „Епилог“ одражава Борхесову резигнацију, али истовремено и олакшање изазвано спознајом о коначности људске имагинације. Ослобођење од сујеверја везаног за неопходност сталног постизања оригиналности одредило је начин Борхесове рецепције свеколике књижевне баштине, а самим тим и суштину његове поетике која се огледа у тумачењу не толико појавне вредности идеја колико њихове изражајне способности деловања, односно, естетичке функције из које управо и произлазе јединствене сензације у машти читалаца (Cervera Salinas 2017: 52-53).

Почетком XXI века збирка Борхесових есеја Друїа истираживања добила је своје прво посебно издање на српском језику, захваљујући издавачкој кући Рaideia из Београда, која је све есеје из овог избора објавила 2008. године у облику засебне књиге под насловом Нова ucuрраживања. Превод са шпанског језика сачинила је Биљана Буквић Исаиловић, а штампани тираж је износио 1.000 примерака.

Скоро три деценије након првог сусрета читалаца на српском језичком подручју са предавачким дискурсом Хорхеа Луиса Борхеса представљеним у збирци Усмени Борхес и gруїa истираживана, београдски издавач Службени гласник објавио је 2012. године, у тиражу

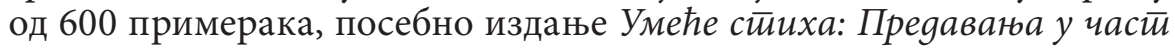
Чарлса Елиой а Норйона, 1967-1968. Ова књига је изашла код нас са временским размаком од дванаест година у односу на појаву (2000. године) оригиналне верзије This Craft of Verse, коју је приредила Калин Андреј Михајлеску, професорка компаративне књижевности на Универзитету у Западном Онтарију, а са енглеског језика превео Лазар Мацура. У састав књиге Умеће стичха улази шест Борхесових предавања, ${ }^{27}$ поговор („О разнородном умећу“) са припадајућим напоменама, који је написала Калин Андреј Михајлеску и два додатна текста („Именски регистар“ и „Појмовни регистар“).

Одложена рецепција посебног издања Умеће стииха до које је дошло на енглеском језичком подручју није умањила значај ових Борхесових предавања нити свежину њиховог књижевно-естетичког доживљаја код читалаца, истиче Калин Андреј Михајлеску, иако су тонски записи у виду магнетофонских трака стајали неискоришћени у подруму библиотеке Универзитета Харвард више од тридесет година (Mihăilescu 2012: 125). Без двоумљења можемо закључити да се истоветан утисак стиче и након закаснеле преводне рецепције поменутих предавања на српском језику. Упоређујући Умеће стииха као својеврстан увод у књижевност, укус и личност самог Борхеса, са Усменим Борхесом, делом које је од првог објављивања 1979. године

27 „Загонетка поезије“, „Метафора“, „Казивање приче“, „Музика речи и превод“, „Мисао поезија“ и „Песников кредо“. 
постало стандардна референца за све хиспанисте и читаоце широм шпанског језичког подручја, Михајлеску закључује да су предавања одржана у Буенос Ајресу нешто мање обимна, те да им Нортонова предавања претходе читаву деценију, представљајући непроцењиву ризницу књижевног блага у есејистичкој, неразметљивој, често ироничној и увек инспиративној форми (Mihăilescu 2012: 125-126). Свих шест предавања која је Борхес одржао на Универзитету Харвард приказано је у поговору књиге Умеће стичха концизно и сувисло, уз поштовање хронолошког критеријума ${ }^{28}$.

Борхесова спознаја књижевности као начина доживљаја света, сматра Калин Андреј Михајлеску, непосредно је утицала на формирање јединственог и неодољивог стила његових предавања, који се у потпуности разликује од грубог и ексцентричног тона већине Борхесових интервјуа и јавних наступа (Mihǎilescu 2012: 127). Ипак, ауторка поговора скреће пажњу читаоцима да их не понесе и не завара благоречивост и приступачност књиге Умеће сйuха, јер она не нуди лако пробављиве лекције о држању предавања, већ је пуна пишчевих најдубљих промишљања. Анализирајући стил овог посебног издања, Михајлеску наглашава да текст књиге Умеће сйuха задржава све основне одлике својствене Борхесовом усменом дискурсу: непосредност, топлину, ток казивања, неформалност, елементе хумора, очаравајуће познавање енглеског језика (Mihăilescu 2012: 127-128). Такође, ауторка поговора истиче Борхесову изузетну ерудицију и невероватне мнемоничке способности: тема о свету као бесконачној библиотеци, која је једна од главних тема целокупног стваралаштва овог писца, неминовно произлази из његовог личног животног искуства, док, с друге стране, предавања, обогаћена мноштвом текстуалних примера, сведоче о дубокој укорењености Борхесове естетике у његовој спознаји књижевности (Mihăilescu 2012: 128). У поговору се помињу бројни извори (Хомер, Вергилије, Беовулф, старонордијске Ege, Хиъаgу и јеgна ноћ, Коран, Библија, Рабле,

28 „Prvo predavanje 'Zagonetka poezije', održano 24. oktobra 1967, bavi se ontološkim statusom poezije i uvodi nas u knjigu kao celinu. 'Metafora' (održano 16. novembra) analizira, po ugledu na Leopolda Lugonesa, način na koji pesnici vekovima koriste iste metaforične obrasce, koji se, po Borhesu, mogu svesti na dvanaest 'suštinskih sličnosti', dok sve ostalo ima za cilj da iznenadi i zato je prolaznog karaktera. U 'Kazivanju priče' (6. decembar), koje je posvećeno epskoj poeziji, Luis Borhes komentariše nezainteresovanost savremenog sveta za epiku, razmišlja o smrti romana i razmatra na koji se način savremeno ljudsko stanje odražava na ideologiju romana: 'Mi, u stvari, ne verujemo u sreću, i to je jedna od nevolja našeg doba.' Ovde on pokazuje sličnost sa Valterom Benjaminom i Francom Kafkom (kojeg je smatrao slabijim piscem od Dž. B. Šoa ili G. K. Čestertona): zalaže se za neposrednost pripovedanja i nastupa nekako kao antiromansijer, pozivajući se na lenjost kao glavni razlog što nje pisao romane. 'Muzika reči i prevod' (28. februar 1968) predstavlja virtuozno razmišljanje o prevođenju poezije. 'Muzika i poezija' (20. Mart) ilustruje više njegovo esejističko nego teorijsko bavljenje položajem književnosti. Iako smatra da je magična muzička istina moćnija od stabilnih fikcija razuma, Luis Borhes tvrdi da je smisao u poeziji fetiš i da snažne metafore pre razbijaju hermeneutičke okvire nego što pojačavaju smisao. Najzad, 'Pesnikov kredo' (10. april) u suštini je ispovedni tekst, neka vrsta književnog testamenta koji je sastavio 'na pola životnog puta'." (Mihăilescu 2012: 126-127) 
Сервантес, Шекспир, Китс, Хајне, По, Стивенсон, Витмен, Џојс) које је Борхес користио на критички начин за припрему Нортонових предавања ${ }^{29}$. Проживљавајући своја сећања на светску књижевну традицију, Борхес је с лакоћом пленио пажњу публике која је слушала његова предавања на Универзитету Харвард, увиђа Калин Андреј Михајлеску, примећујући да је за популарност овог писца делимично заслужан и његов изузетан људски профил, односно, духовитост и углађеност које у подједнакој мери красе сва његова дела, као што су трајно обележиле и читав његов живот (Mihăilescu 2012: 128-129).

Последња збирка Борхесових текстова о књижевности, која је обогатила српску преводну књижевност у посматраном периоду, појавила се у Београду 2013. године под насловом $3 u g u$ књиі $e^{30}$ у издању Службеног гласника и у тиражу од 500 примерака. Реч је о компилацији коју је саставио Радивоје Константиновић, одабравши двадесет три текста из Борхесових Сабраних gела (Obras completas, 1999). Поред приређивача, у превођењу ових текстова са шпанског језика учествовале су Драгана Бајић и Марина Љујић. У односу на сродна посебна издања која су до тада изашла на српском језику, избор 3ug и книіе издваја се својим изразито хетерогеним саставом (два говора, петнаест есеја, три предговора и три предавања). Међутим, треба имати у виду да су скоро сви поменути прилози иницијално већ били објављени у претходним изборима Борхесових текстова о књижевности које је приредио Радивоје Константиновић (Усмени Борхес и яруїа истираживаньа ${ }^{31}$, Оілееди о метиафори з2 и Оїлеgало заїонетики ${ }^{33}$ ). Стога, значај посебног издања $3 u g$ и книіе не лежи у доношењу новина и прављењу значајнијег помака с рецепцијске тачке гледишта, већ се огледа првенствено у учвршћивању постојећег хоризонта очекивања наших читалаца. У том смислу, особити допринос дају два кратка говора („Судбина писца“ и „Не постоји апсолутна естетика“) $)^{34}$ у којима Борхес саопштава, поред захвалности за добијена признања, сопствена књижевна начела и ставове о улози

29 „O književnim teoretičarima nema visoko mišljenje; do kritičara malo drži; a filozofi ga interesuju samo u meri u kojoj se njihove ideje ne odriču sveta zbog čiste apstrakcije" (Mihăilescu 2012: 127).

30 Радивоје Константиновић је за ову компилацију Борхесових текстова изабрао наслов 3 ug и књиіе по есеју „Зид и књиге“ („La muralla y los libros“) из Борхесове збирке огледа Друіа истираживаға.

31 „Скривене чаролије Дон Кихота“ и „Књига“.

32 Избор Оїлеgи о метиафори је преузет у целости, тако да су се сви Борхесови текстови из ове књиге („Метафора“, „Кенинзи“, „Од алегорије ка романима“, „Пасквалова сфера“, „Колриџов цвет“, „Три предговора“) нашли и у избору 3ug и књиіе.

33 „Друкчији Витмен“, „Трајање пакла“, „Флобер и његова узорна судбина“, „Историја вечности“, „О култу књига“, „Китсов славуј“, „Облици једне легенде“, „Зид и књиге, „Огледало загонетки“, „Божанствена комедија“ и „Поезија“.

34 Први говор „Судбина писца“ Борхес је одржао 1980. године приликом примања Награде Сервантес; други говор „Не постоји апсолутна естетика“ одржао је годину дана раније, када је добио Златну медаљу Француске академије. 
писца ${ }^{35}$. Истичући да је свој живот посветио књижевности, нарочито читању, Борхес указује на то да не постоји апсолутна естетика, већ да свака тема условљава сопствену естетику (Borhes 2013: 6). Пишчев задатак се огледа у томе да претвара идеје и осећања у митове, приче и метафоре, који се, потом, обогаћују размишљањима читалаца (Borhes 2013: 7). Узимајући у обзир да наведени ставови одражавају суштину Борхесове поетике, не чуди што је приређивач Радивоје Константиновић одлучио да поменутим говорима започне посебно издање: $3 u g$ и књиіе, док је на крају ове књиге приложио „Поговор“ (претходно објављен у избору Оілеяало заїонейки), као и бројне пратеће прилоге („Објашњења и коментари“, „Напомена приређивача“, „Критичари о Борхесу“, „Хронологија“).

\section{Борхесови текстови о књижевности у антологијама на српском језику посвећеним његовом стваралаштву у целости}

Током последње две деценије ХХ века Радивоје Константиновић је приредио три антологије целокупног стваралаштва Хорхеа Луиса Борхеса, у којима су заступљени, поред одабраних песама и фикционалних творевина у прози, такође и поједини текстови овог хиспаноамеричког писца посвећени књижевности.

Прва од поменутих антологија мешовитог карактера изашла је 1986. године (у тиражу од 2.000 примерака) под насловом Проза. Поезија. Есеј захваљујући издавачкој кући Братство-Јединство из Новог Сада. Ова књига садржи четрнаест есеја, који су преузети из три збирке Борхесових огледа (Друїа истираживана - девет есеја, ${ }^{36}$ Истиорија вечности - два есеја, ${ }^{37}$ Расйрава - три есеја $\left.{ }^{38}\right)$. Поједини од есеја из антологије Проза. Поезија. Есеј већ су одраније били познати нашим читаоцима (један ${ }^{39}$ есеј је претходно изашао 1983. године у збирци Усмени Борхес и gруїа истираживана; три ${ }^{40}$ есеја су објављена 1985. године у збирци Оїлеgи о метиафори). Све Борхесове огледе који су објављени у антологији Проза. Поезија. Есеј превели су са шпанског језика Радивоје Константиновић, Драгана Бајић и Марина Љујић.

Предговор („Необично дело Х. Л. Борхеса“) антологији Проза.

35 „Pisac ne treba suviše da interveniše u svom delu; on treba da bude pasivan, treba da bude gostoprimljiv prema onome što mu dolazi i da obrađuje materijal iz snova" (Borhes 2013: 5). 36 „Зид и књиге“, „Пасквалова сфера“, „Колриџов цвет“, „Скривене чаролије“, „Кафка и његове претече“, „О култу књига“, „Китсов славуј“, „Огледало загонетки“ и „Облици једне легенде“.

37 „Историја вечности“ и „Метафора“.

38 „Друкчији Витмен“, „Трајање пакла“ и „Флобер и његова узорна судбина“.

39 „Кафка и његове претече“.

40 „Метафора“, „Пасквалова сфера“ и „Колриџов цвет“. 
Поезија. Есеј написао је Радивоје Константиновић. Посматрајући $\mathrm{XX}$ век као епоху радикалног преиспитивања универзалног културног наслеђа, Константиновић види у Хорхеу Луису Борхесу оличење синтезе којом би се обухватило свеколико уметничко и људско искуство нашег и свих претходних векова. Полазећи од констатације да се у Борхесовом систему вредности прочитано изједначава са доживљеним, Константиновић пореди Борхесово схватање оригиналности са Монтењевим, те истиче да Борхес у ствари одбацује концепт заснован на неговању иновација и оригиналности, јер сматра да у уметности вреди само оно што је архетипско, то јест препознатљиво, да би развио сопствени концепт дуалне функције уметничког дела као, с једне стране, готовог производа, а, с друге стране, као градивног материјала погодног за стварање нових дела (Konstantinović, „Neobično delo H. L. Borhesa“, 1986: 6). Са намером да продре у срж односа човек-свет, Борхес обрађује низ метафизичких тема (пролазност, смисао живота, смрт, идентитет, срећа) и за њихово означавање користи вечне, свима добро познате симболе, док метафорама настоји да искаже саму суштину; потом, када у есејима анализира метафору као омиљену стилску фигуру многих аутора, Борхес уједно саопштава читаоцима основне смернице за разумевање и тумачење сопственог дела у којем се нераскидиво преплићу поезија, фикција и филозофска промишљања (Konstantinović, „Neobično delo H. L. Borhesa“, 1986: 13).

Имајући у виду знатно спорију рецепцију Борхесових есеја у односу на пријем његових песама и прича, Константиновић примећује да би утицај Хорхеа Луиса Борхеса на модерну критику био знатно већи него што се одвијао са закашњењем од три-четири деценије, да су којим случајем његови есеји били преведени у Европи непосредно после објављивања, двадесетих и тридесетих година прошлог века (Konstantinović, „Neobično delo H. L. Borhesa“, 1986: 21). Уверење, експлицитно изражено још 1933. године, да свака критика мора полазити од текста, учинило је Борхеса претечом модерне критике, истиче аутор предговора, указујући на главне одлике Борхесових есеја: већином су кратки по обиму, а сваки од њих је права интелектуална авантура у којој се избегавају уопштена тврђења и нуде неочекивани закључци, уз обиље доказног материјала у облику бројних цитата (Konstantinović, „Neobično delo H. L. Borhesa“, 1986: 21-22). Упоређујући Борхеса са Прустом, Елиотом и Паундом, Радивоје Константиновић с правом сматра да Борхесово критичко дело садржи елементе једне модерне естетике, премда код са̂мог Борхеса уочава извесну одбојност према уобличавању посебног, целовитог, естетичког система. Наглашавајући конвергентност свих књижевних активности Хорхеа Луиса Борхеса и јединственост његовог литерарног стваралаштва у којем је тешко одредити јасне границе између песама, прича и есеја, Константиновић, на крају предговора, 
указује на непролазну актуелност и универзалност Борхесовог дела у целости (Konstantinović, „Neobično delo H. L. Borhesa“, 1986: 22).

Антологија Проза. Поезија. Есеј употпуњена је пратећим прилозима информативног карактера („Напомена приређивача“, „Напомене и коментари“), чији је аутор Радивоје Константиновић. Са рецепцијске тачке гледишта посебно је драгоцена „Напомена приређивача“, јер указује на критеријуме и циљеве којима је Константиновић стремио приликом припреме овог избора. Жеља да што боље представи богатство идеја и стваралачки распон једног од највећих писаца XX века, условила је тематску разноврсност одабраних текстова, а намера да радозналом читаоцу разјасни поједине цитате, алузије и податке о личностима које Борхес спомиње у својим есејима, довела је приређивача до састављања „Напомена и коментара“, што је изискивало додатна, веома исцрпна истраживања ${ }^{41}$. Присуство поменутих помоћних текстова умногоме је допринело бржој и лакшој рецепцији антологије Проза. Поезија. Есеј, нарочито када се има у виду да је овај избор био прво посебно издање такве врсте које је ушло у видокруг очекивања наших читалаца.

Почетком последње деценије XX века београдска издавачка кућа Просвета је објавила (1992. године), у тиражу од 3.000 примерака, антологију Изабрана ӣроза и йоезија, други по реду избор из богате књижевне заоставштине Хорхеа Луиса Борхеса који је приредио Радивоје Константиновић. У поређењу са антологијом Проза. Поезија. Есеј), компилација Изабрана ӣроза и йоезија садржи упола мање Борхесових текстова о књижевности, односно, обухвата седам таквих прилога, који су већ били познати нашим читаоцима (пет огледа ${ }^{42}$ је заступљено у антологији Проза. Поезија. Ecej, а један оглед ${ }^{43}$ и три предговора ${ }^{44}$ изашли су у збирци Оїлеgu о метиабори). Сви Борхесови текстови о књижевности из антологије Изабрана ūpoза u йоезија нашли су се пред нашом читалачком публиком у преводу са шпанског језика који је сачинио Радивоје Константиновић. Предговор „Необично дело Х. Л. Борхеса“ као и „Напомена приређивача“ такође су преузети из антологије Проза. Поезија. Ecej. Остале пратеће текстове („Напомене и коментари“, „Критичари о Борхесу“, „Хронологија“) приређивач је припремио за потребе оп-

41 „To nije bio lak posao jer nijedno nama poznato originalno izdanje Borhesovih dela nema komentara. Mnogi od navedenih podataka ne mogu se naći ni u najvećim enciklopedijama - do njih se može doći samo čitanjem veoma obimne literature: to pogotovu važi za podatke vezane za Borhesovu biografiju i život u Buenos Airesu dvadesetih i tridesetih godina našeg veka“ (Konstantinović, „Napomena priređivača“, 1986: 274).

42 „Зид и књиге“, „Пасквалова сфера“, „Колриџов цвет“, „Огледало загонетке“ и „Облици једне легенде“.

43 „Од алегорије ка романима“.

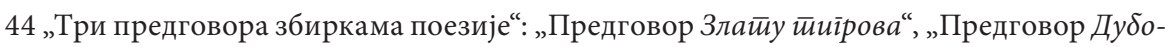
кој ружи“ и „Предговор Шифри“. 
ремања антологије Изабрана йроза и йоезија.

У погледу доприноса ширењу хоризонта очекивања реципијената са српског језичког подручја посебно је значајан прилог „Критичари о Борхесу“. Користећи бројне иностране и домаће изворе (књижевне часописе, зборнике, монографије), Радивоје Константиновић је издвојио, превео са одговарајућег (француског, шпанског) језика и објединио у складну композициону целину, дванаест критичких мишљења еминентних аутора о стваралаштву Хорхеа Луиса Борхеса, од којих се пет коментара односи на Борхесову есејистику и његово схватање књижевности као уметности речи: Валери Ларбо ${ }^{45}$ сматра да Борхесова збирка есеја Исӣраживана (Inquisiciones, 1925) ${ }^{46}$ представља почетак нове етапе у развоју аргентинске критике, јер обједињује елементе из француске, енглеске, немачке, шпанске и италијанске културе и, на тај начин, шири видокруг интелектуалаца из читаве Латинске Америке; Жерар Женет ${ }^{47}$ истиче да се у Борхесу отелотворују најчистије традиције хуманизма, које му дозвољавају да сугерише два могућа начина интерпретације књижевности, односно, с једне стране, екстремни или „пантеистички“ модалитет према којем јединствени дух обитава у привидном мноштву писаца и њихових творевина, омогућавајући да јунак другог дела романа Дон Кихой постане читалац његовог првог дела, и, с друге стране „класичан“ приступ, доминантан све до почетка XIX века, у којем постојање мноштва различитих аутора није од посебног значаја, будући да се у књижевним делима не тражи одраз телесности њихових твораца; Гиљермо Сукре ${ }^{48}$ указује на суштински параметар Борхесове естетике, заснован на истицању активне улоге читаоца који вођен сопственом слободном вољом врши различите изборе у процесу рецепције књижевног текста; Данило Киш сматра да Борхес формира субјективно - више лирско него интелектуално - виђења света, свестан узалудности покушаја стварања „резимеа“ свеколике људске историје, чије се извориште не налази у колективној свести него у писаним споменицима; Леонардо Шаша ${ }^{49}$, на основу спознаје да кључ за читање целокупног Борхесовог дела лежи у једној реченици из збирке Друїа истираживања, у којој се тврди да је сваки образован човек у ствари теолог, сагледава Борхеса као атеистичког теолога свога

45 Валери Ларбо (Valéry Larbaud, 1881-1957), француски писац, песник, критичар и есејиста из прве половине XX века.

46 Истираживана (Inquisiciones), прва објављена збирка есеја Хорхеа Луиса Борхеса на шпанском језику, изашла је у Буенос Ајресу 1925. године, у штампарији Инка (El Inca), у тиражу од 500 примерака.

47 Жерар Женет (Gérard Genette, 1930), француски теоретичар књижевности и један од зачетника наратологије.

48 Гиљермо Сукре (Guillermo Sucre, 1933), венецуелански песник, преводилац и књижевни критичар.

49 Леонардо Шаша (Leonardo Sciascia, 1921-1989) један од најзначајнијих италијанских писаца XX века, чије је стваралаштво снажно обележено сицилијанством. 
времена у чијем се стваралаштву одражавају бројне противречности ХХ века (Константиновић 1992: 273-282). Премда селективан, прилог „Критичари о Борхесу“ је у знатној мери утицао на бољу рецепцију Борхесових текстова о књижевности из антологије Изабрана йроза

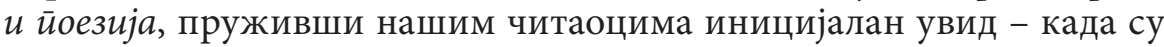
у питању посебна издања на српском језику - у интерпретативну рецепцију Борхесовог есејистичког стваралаштва која се развијала на међународној књижевној сцени од 1925. до 1988. године.

Борхесови есеји из антологије Изабрана ӣроза и йоезија срећу се поново у трећем избору који је Радивоје Константиновић приредио током XX века из стваралаштва овог хиспаноамеричког писца, а објавила 1995. године београдска издавачка агенција Драганић под насловом Изабрана gела: ӣроза, йоезија, есеји у тиражу од 2.000 примерака. Почетком XXI столећа ово посебно издање појављује се још једном, прештампано 2006. године код истог издавача, са тиражем од 1.000 примерака.

\section{Завршне напомене}

Борхесови текстови о књижевности, у које спадају не само огледи већ и предавања и предговори, почели су да улазе у хоризонт очекивања наше читалачке публике током раних осамдесетих година прошлог века, скоро у исто време када и песничке творевине овога хиспаноамеричког аутора, а знатно касније у односу на иницијални пријем (1963. године) његове приповедне прозе. У раздобљу од скоро три деценије (од 1983. до 2013. године) код нас је објављено једанаест посебних издања која су у целости била посвећена Борхесовим текстовима о књижевности и три антологије мешовитог карактера у којима су такви текстови били заступљени заједно са Борхесовим одабраним песмама и приповеткама. Ова преводна рецепција је била знатно интензивнија у XX веку, када је у виду различитих издања (прво, друго, треће) изашло седамнаест од укупно двадесет две књиге објављене током посматраног раздобља. За изворе су коришћене првенствено поједине збирке Борхесових есеја, предавања и предговора, које су стизале до нас са веома различитим временским дистанцама у односу на појаву оригинала на шпанском језику: период усвајања је варирао од свега две године (Biblioteca personal. Prólogos, 1988 - Преgīoвори, 1990) до скоро пола века (Historia de la eternidad, 1936 - Оїлеgи о мейабори, 1985). Борхесове збирке есеја, као и збирке предавања, најчешће су парцијално улазиле у хоризонт очекивања наших читалаца. Понекада, комплетан корпус поједине Борхесове збирке је био уврштен, заједно са есејима овог писца одабраним из других извора, у шири избор приређен на српском језику (Усмени Борхес и gруїа истираживана, 1983; Истиорија вечностии и gруїи есејu, 1999). Међутим, засебна издања у целости посвећена ис- 
кључиво одређеној збирци Борхесових есеја или предавања почела су да се објављују на српском језику знатно касније, тек крајем прошлог и почетком овог века (Усмени Борхес, 1990; Истиорија вечностии, 1999; Друїа исирраживаюа, 2008).

Борхесови текстови о књижевности нашли су се пред нашим читаоцима у преводима насталим (са изузетком збирке Умеће сиииха коју је са енглеског језика превео Лазар Мацура) непосредно са шпанског језика, захваљујући нашим преводиоцима Радивоју Константиновићу, Силвији Монрос Стојаковић, Кринки Видаковић Петров, Драгани Бајић, Марини Љујић, Милану Комненићу, Радици Остојић, Анђелији Станојевић, Предрагу Марковићу и Биљани Буквић Исаиловић. У највећем броју случајева преводиоци су били и приређивачи избора, као и састављачи одговарајуће пратеће апаратуре (предговора и/или поговора, напомена, коментара, регистара и хронолошких прегледа).

У представљању Борхесових текстова о књижевности читалачкој публици на српском језичком подручју посебно су се истакли Радивоје Константиновић и Силвија Монрос Стојаковић. Приредивши шест посебних издања (три избора из Борхесовог есејистичког стваралаштва и три антологије из целокупног опуса овог писца) употпуњена одговарајућим поговорима и исцрпним коментарима, Радивоје Константиновић је у највећој мери заслужан за почетно формирање, модификовање и учвршћивање хоризонта очекивања наших читалаца, док се Силвија Монрос Стојаковић истакла у преводној рецепцији Борхесових предговора и есеја о будизму. У највећем броју случајева, посебна издања која су приредили Радивоје Константиновић и Силвија Монрос Стојаковић била су вишеструко прештампавана (Шийа је буgизам, 1989, 1990, 1991, 1994, 1995, 1999; Преgїовори, 1990, 1995, 1999; Изабрана gела: йроза, йоезија, есеј, 1995, 2006).

Преводна рецепција Борхесових текстова о књижевности одвијала се у најзначајнијим издавачким центрима у Србији и у њој је учествовало четрнаест издавачких кућа: најзаступљенији су били издавачи из Београда (Стилос, No Limit Books, Бата, Рад, Просвета, Силмир, Драганић, Народна књига - Алфа, Paideia, Службени гласник), а потом из Новог Сада (Братство-Јединство, Светови), Ниша (Градина) и Чачка (Градац). Најчешће се у том погледу ангажовао издавач Силмир, објављујући у више наврата Борхесова дела Шӣа је буguзам $(1994,1995,1999)$ и Шийа йоново чийам $(1995,1999)$. Током истраженог периода уочено је постојање самосталних издавачких активности које су се одвијале за време девете деценије прошлог века: иницијални пробој хоризонта очекивања читалаца са српског језичког подручја, када се ради о Борхесовим текстовима о књижевности, остварио се управо захваљујући самосталном ауторском издању у облику збирке одабраних предавања и есеја Хорхеа Луиса Борхеса (Усмени Борхес и gруіа истираживаюа) које су (1983. године) реализовали Предраг Марковић, Светислав Басара, Михајло Пантић и Томица Милосављевић, 
док је први сусрет (1989. године) наше читалачке публике са Борхесовим делом Шійа је буguзам резултат индивидуалног (преводилачког и издавачког) прегалаштва Силвије Монрос Стојаковић. Тиражи у којима су штампана посебна издања са Борхесовим текстовима о књижевности на српском језику варирали су од 500 до 3.000 примерака. Већи тиражи су својствени издањима објављеним у XX столећу, док су у овом веку углавном износили 1.000 примерака; изузетак чине антологије у којима је представљено целокупно Борхесово стваралаштво, чији су тиражи у просеку достизали 2.000 примерака.

Током прошлог и овог века, у оквиру преводне рецепције Борхесових текстова о књижевности која је остварена на српском језику у облику посебних издања, из обимне књижевне заоставштине Хорхеа Луиса Борхеса преведене су на српски језик у целости три збирке есеја (Истиорија вечностии, Друіа истираживаюа, Шйа је буgизам), две збирке предавања (Усмени Борхес, Умеће стихха) и једна збирка предговора (Лична библиоиеека. Преgіовори), док су различите верзије његових сабраних дела (Сабрана йроза, Песничко gело, Сабрана gела), као и одређене збирке огледа и предавања (Расйрава, Сеgам ноћи) из којих су одабрани и преведени поједини текстови, парцијално ушле у видокруг очекивања наших читалаца. На тај начин, читава палета најразноврснијих тема, пре свега оних везаних за књижевност, али и за друга поља Борхесових интересовања (филозофија, историја, религија, естетика) којима се овај хиспаноамерички писац бавио читавог живота, постала је доступна читалачкој публици са српског језичког подручја.

Најзначајнији допринос проширењу видокруга очекивања наших читалаца остварен преводном рецепцијом Борхесових текстова о књижевности огледа се у продору и пријему иновација које су ове творевине донеле у погледу спознаје не само суштине Борхесове есејистике, већ и његовог схватања основне функције књижевности, пре свега, односа који постоји између аутора, текста и читаоца. Борхес у потпуности изједначава специфичне особине аутора са категоријом читаоца: аутор не само да своје комбинације и варијације чита из заједничке књижевне традиције већ своју моћ читања примењује и на текстове трансцендентних аутора, односно ишчитава и свет, трагајући за архетиповима, а елементе књижевног текста употребљавају само као средства за наслућивање метафизичких појмова, који се не могу рационално фиксирати, те стога користе или наративне или поетске форме јер оне на најбољи начин дочаравају (са нагласком на магијском корену ове речи) и сугеришу те неухватљиве појмове (Milutinović 2015: 166-167).

Поимање књижевности као јединственог система, састављеног од ограниченог броја елемената, односно слика и правила умрежених у бесконачан низ различитих комбинација у којем се стално мешају оригинали и мноштво копија, довело је Хорхеа Луиса Борхеса 
до схватања да је тумачење било које теме континуирана и кружна појава, што га је подстакло да уведе квалитативне промене у сопствени књижевни дискурс и редефинише уобичајене циљеве које треба да испуни есеј (Oviedo 2003). Будући да фантастику сматра основним аксиолошким, естетским, епистемолошким и онтолошким мерилом на основу којег вреднује све појаве, Борхес одбацује да се угледа на поједине ауторе и њихова дела, те подражава само текстове са елементима фантастике; међутим, имајући у виду да је фантастично по својој природи превасходно естетска, књижевна категорија, произлази да Борхес ишчитава све текстове као књижевне, укључујући и појаве света и универзума, које је такође сматрао текстовима (Milutinović 2015: 162). На тај начин, изузетна тематска разуђеност и оригиналност испољена у обради грађе одликују Борхесов опус у целости, а посебно долазе до изражаја у есејима, који у знатној мери доприносе бољем разумевању естетичких ставова и стилских поступака примењених у фикционалним творевинама овог аутора.

Преводна рецепција Борхесових текстова о књижевности има веома значајну улогу у прихватању целокупног стваралаштва овог хиспаноамеричког писца на српском језичком подручју. Објављене збирке Борхесових есеја, предавања и предговора сведоче о високом нивоу реализације поменутог рецепцијског процеса током којег је оформљен стабилан видокруг очекивања, погодан за даље модификације, проширења и консолидацију књижевног укуса наше читалачке публике.

\section{ИЗВОРИ}

Borhes, Horhe Luis. Usmeni Borhes i druga istraživanja. Preveli sa španskog Anđelija Radovanović, Radica Ostojić i Predrag Marković. Beograd: Samostalno autorsko izdanje: Predrag Marković, Svetislav Basara, Mihajlo Pantić i Tomica Milosavljević, 1983.

------- Оїлеgи о метиафори. Превели са шпанског Радивоје Константиновић и Драгана Бабић. Ниш: Градина, 1985.

-------- Proza. Poezija. Esej. Priredio Radivoje Konstantinović. Preveli sa španskog Radivoje Konstantinović, Dragana Bajić i Marina Ljujić. Novi Sad: Bratstvo-Jedinstvo, 1986.

Šta je budizam. Prevela sa španskog Silvia Monros Stojaković. Beograd: Autorsko štamparsko delo, 1989.

- Predgovori. Prevela sa španskog Silvia Monros Stojaković. Beograd: Stilos, 1990.

Šta je budizam. Prevela sa španskog Silvia Monros Stojaković. Beograd: Bata, 1990.

- Usmeni Borhes. Preveli sa španskog Anđelija Stanojević i Predrag Marković. Beograd: Rad, 1990. 
Šta je budizam. Prevela sa španskog Silvia Monros Stojaković. Beograd: Bata, 1991.

Изабрана йроза и йоезија. Приредио Радивоје Константиновић. Превели са шпанског Радивоје Константиновић, Драгана Бајић и Марина Љујић. Београд: Просвета, 1992.

Šta je budizam. Prevela sa španskog Silvia Monros Stojaković. Beograd: Silmir, 1994.

Изабрана gела: йроза, йоезија, есеј. Приредио Радивоје Константиновић. Превели са шпанског Радивоје Константиновић, Драгана Бајић и Марина Љујић. Београд: Издавачка агенција Драганић, 1995.

Оілееgало заїонейки: есеји о књижевностии. Приредио Радивоје Константиновић. Превели са шпанског Радивоје Константиновић, Драгана Бајић и Марина Љујић. Нови Сад: Светови, 1995.

Šta je budizam. Prevela sa španskog Silvia Monros Stojaković. Beograd: Silmir, 1995.

Šta ponovo čitam (Predgovori). Prevela sa španskog Silvia Monros Stojaković. Beograd: Silmir, 1995.

Istorija večnosti i drugi eseji. Prevela sa španskog Krinka Vidaković Petrov. Beograd: Narodna knjiga - Alfa, 1999.

Šta je budizam. Prevela sa španskog Silvia Monros Stojaković. Beograd: Silmir, No Limit Books, 1999.

Šta ponovo čitam (Predgovori). Prevela sa španskog Silvia Monros Stojaković. Beograd: Silmir, 1999.

- Istorija večnosti. Preveo sa španskog Milan Komnenić. Beograd: Branko Kukić, Čačak: Umetničko društvo Gradac, 2005.

Изабрана gела: ирроза, йоезија, есеј. Приредио Радивоје Константиновић. Превели са шпанског Радивоје Константиновић, Драгана Бајић и Марина Љујић. Београд: Издавачка агенција Драганић, 2006.

Nova istraživanja. Prevela sa španskog Biljana Bukvić Isailović. Beograd: Paideia, 2008.

- Umeće stiha: predavanja u čast Čarlsa Eliota Nortona: 1967-1968. Preveo sa engleskog Lazar Macura. Beograd: Službeni glasnik, 2012.

- Zid i knjige: ogledi o književnosti. Priredio Radivoje Konstantinović. Preveli sa španskog Radivoje Konstantinović, Dragana Bajić i Marina Ljujić. Beograd: Službeni glasnik, 2013.

\section{ЛИТЕРАТУРА}

Balderston, Daniel. Out of Context: Historical Reference and the Representation of Reality in Borges. Durham and London: Duke University Press, 1993.

Константиновић, Радивоје. „Борхесова метафора“ (поговор). Оїлеgи o метиафори. Хорхе Луис Борхес. Ниш: Градина, 1985. 33-36. 
„Neobično delo H. L. Borhesa“ (predgovor). Proza. Poezija. Esej. Horhe Luis Borhes. Nov Sad: Bratstvo-Jedinstvo, 1986. 5-22.

------- „Napomena priređivača“. Proza. Poezija. Esej. Horhe Luis Borhes. Nov Sad: Bratstvo-Jedinstvo, 1986. 274.

-------- (изабрао и превео). „Критичари о Борхесу“. Изабрана йроза и йоезија. Хорхе Луис Борхес. Београд: Просвета, 1992. 273-282.

------- „Поговор“. Оїлеgало заіонейки: есеји о книжевностии. Хорхе Луис Борхес. Нови Сад: Светови, 1995. 176-178.

------- „Pogovor“. Zid i knjige: ogledi o književnosti. Horhe Luis Borhes. Beograd: Službeni glasnik, 2013. 165-166.

Castany Prado, Bernat. „Reformulación escéptica del género policial en la obra de Jorge Luis Borges“. Tonos - Revista electrónica de estudios filológicos 11 (2006) без пагинације. <https://www.um.es/tonosdigital/ znum11/estudios/6-bernatcastany.htm> 10. 12. 2017.

Kot, Jan. „Umesto pogovora: Zagonetka Šekspira“ (pogovor). Usmeni Borhes i druga istraživanja. Horhe Luis Borhes. Beograd: Samostalno autorsko izdanje: Predrag Marković, Svetislav Basara, Mihajlo Pantić i Tomica Milosavljević, 1983. 83-85.

Marković, Predrag. „ On, Borhes, prvi i drugi“ (pogovor). Usmeni Borhes. Horhe Luis Borhes. Beograd: Rad, 1990. 75-81.

Milutinović, Dejan. Poetica Borgesiana. Književnost po H. L. Borhesu. Niš: Niški kulturni centar, 2015.

Mihajlesku, Kalin-Andrej. „O raznorodnom umeću“ (pogovor). Umeće stiha: Predavanja u čast Čarlsa Eliota Nortona: 1967-1968. Horhe Luis Borhes. Beograd: Službeni glasnik, 2012. 125-129.

Monros Stojaković, Silvia. „Čovek iz ulice sa ružičastim dućanom i ljudi u čaršavima boje šafrana“ (pogovor). Šta je budizam. Horhe Luis Borhes. Beograd: Autorsko štamparsko delo, 1989. 127-147.

------- „U pogovoru Predgovorima“ (pogovor). Predgovori. Horhe Luis Borhes. Beograd: Stilos, 1990. 146-148.

Oviedo, José Miguel. „Borges: El ensayo como argumento imaginario“. Letras Libres 31 agosto 2003, без пагинације. <http://www.letraslibres.com/ mexico/borges-el-ensayo-como-argumento-imaginario> 6. 9. 2017.

Pavlović-Samurović, Ljiljana. Leksikon hispanoameričke književnosti. Beograd: Savremena administracija, 1993. 316-328.

Pérez, Alberto Julán. „Génesis y desarrollo de los procedimientos narrativos en la obra literaria de Jorge Luis Borges“. Jorge Luis Borges: variaciones interpretativas sobre sus procedimientos literarios y bases epistemológicas. Karl Alfred Blüher [et al.]. Frankfurt am Main: Vervuert Verlag, 1992. 11-27.

-------_,Jorge Luis Borges: El oficio del lector“. Revista de Literaturas Modernas 29 (1999): 249-271.

<http://bdigital.uncu.edu.ar/objetos_digitales/5041/perezrlmodernas 29. pdf> 10.9. 2017.

Cervera Salinas, Vicente. „El culto del libro, culto de Borges“. Estudios Románicos 26 (2017), 51-61. 
Vesna Dickov

Mirrors in a Labyrinth: Translations of Borges's Texts on Literature in Separate Publications in Serbian

\section{Summary}

Borges's texts on literature, which include not only essays but also lectures and prefaces, have begun entering into the horizon of expectations of our reading audience during the early 1980s, almost at the same time as the poetic creations of this Hispano-American author, and much later in relation to the initial reception (1963) of his narrative prose. In the period of almost three decades, that is from 1983 to 2013, eleven special editions were published, which were entirely dedicated to Borges's texts on literature and three mixed-matter anthologies in which such texts were represented along with Borges's selected poems and stories.

From the extensive literary legacy of Jorge Luis Borges, three essay collections (History of Eternity, Other Research, What is Buddhism), two collections of lectures (Oral Borges, This Craft of Verse) and a collection of prefaces (Personal Library. Prefaces) were translated into Serbian. Various versions of his collected works, as well as some collections of essays and lectures (Discussion, Seven Nights) from which certain texts were selected and translated into Serbian, entered partially into the horizon of expectations of the Serbian readers.

All these Borges's texts on literature were translated directly from the Spanish language (with the exception of Lazar Macura's translation of the book This Craft of Verse from English), thanks to our eminent translators Radivoje Konstantinović, Silvia Monros Stojaković, Krinka Vidaković Petrov, Dragana Bajić, Marina Ljujić, Milan Komnenić, Radica Ostojić, Anđelija Stanojević, Predrag Marković and Biljana Bukvić Isailović, who in most cases were also the editors.

This type of reception of Borges's texts on literature was held in the most important publishing centers in Serbia and it included fourteen publishers: the most popular were publishers from Belgrade (Stilos, No Limit Books, Bata, Rad, Prosveta, Silmir, Draganić, Narodna knjiga-Alfa, Paideia, Službeni glasnik), Novi Sad (Bratstvo-Jedinstvo, Svetovi), Niš (Gradina) and Čačak (Gradac). The circulation of the editions with Borges's texts on literature in Serbian varied from 500 to 3,000 copies.

Borges's texts on literature greatly contribute to a better understanding of his poetics in general as well as the stylistic procedures applied in the fictional creations. Therefore, the translatory reception of Borges's texts on literature plays a very important role in accepting his entire work in the Serbian linguistic field. The published collections of Borges's essays, lectures and prefaces testify to the high level of this reception during which a stable horizon of expectations was created, suitable for further modifications, enlargements and consolidation of literary taste of the Serbian readers.

Keywords: Hispano-American literature, Serbian translations, Jorge Luis Borges, lectures, essays, prefaces, reception 